\title{
Circulating immunoglobulin G1 antibody in patients with ulcerative colitis against the colonic epithelial protein detected by a novel monoclonal antibody
}

\author{
A Dasgupta, A Mandal, K M Das
}

\begin{abstract}
Autoimmunity has been implicated in the pathogenesis of ulcerative colitis (UC). Several studies have shown amplified immunoglobulin G1 (IgG1) antibody response in UC; however the immunoreactive antigen(s) is unknown. To study this antigen(s), mucosal colonic extract was prepared by sonication, ultracentrifugation followed by ion exchange chromatography in fast protein liquid chromatography. The fraction (enriched colonic peptide), that was most reactive to a novel monoclonal antibody, $7 \mathrm{E}_{12} \mathrm{H}_{12}$ (IgM isotype), was isolated and used to examine the immunoreactivity against the patients' serum samples. Two hundred and thirteen coded samples from 111 patients with UC (symptomatic and untreated (63), symptomatic and treated (26), remission (22)); 47 with Crohn's disease (CD) (40 were symptomatic and untreated, and 30 had colonic disease); 29 with acute diarrhoea caused by specific pathogen(s); 10 with systemic lupus erythematosus, and 16 normal subjects were examined against the enriched colonic peptide by IgG subtype specific enzyme linked immunosorbent assays (ELISAs). Total IgG antibody reactivity was significantly $(p<0.01)$ higher only in symptomatic and untreated UC patients compared with each of the non-UC group, but the sensitivity was only $50 \%$. IgG 2 and IgG3 reactivities were not different among various groups. The IgG1 antibody reactivity against the enriched colonic peptide, however, differentiated UC patients from $C D$ and each of the other non-UC groups. Seventy nine per cent of the patients with UC, treated or untreated, symptomatic or in remission, had significantly $(p<0.0001)$ higher IgG1 antibody against the enriched colonic peptide when compared with each of the other non-UC groups. Only $12 \%$ of CD serum samples and none of the other control serum samples reacted. Using purified serum IgG1 and $7 \mathrm{E}_{12} \mathrm{H}_{12}-\mathrm{IgM}$, by sandwich ELISA, we confirmed that $7 \mathrm{E}_{12} \mathrm{H}_{12}$ reactive peptide indeed reacts with UC-IgG1 antibody but not with control IgG1.
\end{abstract}

(Gut 1994; 35: 1712-1717)
Although the cause of ulcerative colitis (UC) is unknown, autoimmunity plays an important part in its pathogenesis. ${ }^{1}$ Serum autoantibodies to colonic epithelial cells have been identified in up to $60 \%$ of patients with $\mathrm{UC}^{2-4}$ and occur at a lower frequency in their relatives. ${ }^{5}$ The autoantibodies have been described both against colonic goblet cells as well as absorbtive epithelial cells. In UC, an amplified immunoglobulin G1 (IgG1) antibody response in the circulation ${ }^{6}$ and in situ $^{7}$ have been reported. In the second group there was also deposition of IgG1 together with activated early (C1q, C4c, C3b) and late (terminal complement complex) components of the complement cascade, on the apical face of the colonic epithelium in patients with active UC but not in patients with Crohn's colitis. ${ }^{78}$ The immunoreactive antigen(s) recognised by the IgG1 antibody is, however, unknown. Tissue bound IgG, eluted from colonic mucosa, has been shown to react with an $\mathrm{Mr} 40 \mathrm{~K}$ colonic protein (P40) only when the IgG was obtained from UC lesions. ${ }^{9}$ The UC colon eluted IgG (CCA-IgG) also reacted with P40 from the autologous colon further supporting its autoantigenicity. ${ }^{9}$ The subclass of CCA-IgG is unknown.

A monoclonal antibody $\left(7 \mathrm{E}_{12} \mathrm{H}_{12}, \quad\right.$ IgM isotype) against highly enriched $\mathrm{P} 40$ was developed and the reactivity of the monoclonal antibody was specifically localised to colonic epithelium and not in 13 other epithelial organs including other parts of the gastrointestinal tract and small intestinal enterocytes. ${ }^{10}$ Using a three colour immunofluorescence technique, recently epithelial deposits of IgG1 autoantibody and activated complement were colocalised along with the $7 \mathrm{E}_{12} \mathrm{H}_{12}$ reactive peptide on the colonic epithelium from patients with active UC and not from patients with Crohn's disease (CD) affecting the colon. ${ }^{11}$

In this study, we have examined the presence of circulating autoantibodies and their subclasses in patients with UC against the colonic epithelial protein highly enriched for the $7 \mathrm{E}_{12} \mathrm{H}_{12}$ reactivity. The disease specificity and sensitivity were examined using serum samples from a large number of patients with UC, CD, colitides resulting from specific pathogens and another autoimmune disease, systemic lupus erythematosus. The influence 
of the activity of the disease and effect of treatment against the immunoreactivity was also examined.

\section{Methods}

PREPARATION OF COLON EXTRACT HIGHLY ENRICHED IN $7 \mathrm{E}_{12} \mathrm{E}_{12}$ REACTIVE PEPTIDE (ENRICHED COLON EPITHELIAL PEPTIDE)

Twelve specimens of colon (normal segments) were obtained from patients undergoing colectomy for colon cancer. The mucosa was carefully stripped off the muscle layer and the mucosal tissue was minced in $50 \mathrm{ml}$ of buffer A, containing $50 \mathrm{mM}$ TRIS $\mathrm{HCl}, \mathrm{pH} 8 \cdot 0,0 \cdot 15$ $\mathrm{M} \mathrm{NaCl}, 2 \mathrm{mM}$ EDTA, $2 \mathrm{mM}$ phenylmethylsulphonylfluoride, $0.3 \mu \mathrm{m}$ aprotinin, $1 \mu \mathrm{M}$ pepstatin, and $1 \mu M$ leupeptin (Boehringer Manheim, Indianapolis, Indiana). The tissue was washed in the same buffer at least seven times until the supernatant was clear. The final pellet was homogenised in buffer A with $10 \mathrm{mM}$ EDTA. The homogenate was centrifuged at $10000 \times g$ for 30 minutes. The resulting supernatant was ultracentrifuged at $100000 \times g$ for 90 minutes. The supernatant was frozen and thawed three times, then centrifuged for 10 minutes at $10000 \times g$ to remove precipitates. The supernatant was dialysed against $20 \mathrm{mM}$ bis-TRIS propane, $\mathrm{pH} 6.5$ (buffer B) at $4^{\circ} \mathrm{C}$. To remove lipids, the supernatant was mixed vigorously with an equal volume of 1,1,2-trichlorotrifluoroethane (Sigma, St Louis, MO), and centrifuged. The aqueous phase was filtered through $0 \cdot 20$ micron cellulose acetate membrane filter. The filtrate was then subjected to anion exchange chromatography using a Mono $Q$ HR 5/5 column (Pharmacia Fine Chemicals, Piscataway, NJ) in fast protein liquid chromatography (FPLC). Five mg of the colon extract were loaded in the column, which was then washed with buffer B. Proteins were eluted with a step gradient of $0.2,0.35$, and $0.48 \mathrm{M} \mathrm{NaCl}$ in buffer $\mathrm{B}$. The immunoreactivity of the various eluates was examined in an ELISA using $7 \mathrm{E}_{12} \mathrm{H}_{12}$ monoclonal antibody. ${ }^{10}$ The $0.48 \mathrm{M} \mathrm{NaCl}$ colon extract was highly enriched for the $7 \mathrm{E}_{12} \mathrm{H}_{12}$ reactive peptide and used for the ELISA as described below.

\section{IMMUNOREACTIVITY OF THE ENRICHED} COLONIC PEPTIDE AGAINST PATIENTS SERUM SAMPLES

In preparation for the ELISA analysis, blood serum was obtained from a total of 203 subjects. These included 111 patients with UC, 47 with CD, 29 colitides, 10 patients with systemic lupus erythematosus, and 16 normal subjects. UC and CD were diagnosed on the basis of the patient's clinical history, sigmoidoscopic, or colonoscopic examinations, or all three, and radiographic and histological studies of intestinal specimens. The activity of the disease was assessed by the physicians and noted in a specific protocol while collecting the blood samples. The colitides patients were diagnosed on the basis of their stool examina- tion for specific pathogens. All serum samples were decomplemented by heating at $56^{\circ} \mathrm{C}$ for 30 minutes, then delipidated by treating with equal volume of 1,1,2-trichlorotrifluoroethane, and ultracentrifuged at $100000 \times g$ for 30 minutes to remove aggregates.

\section{DIRECT ELISA}

Ninety six wells microtitre plates (Immulon IV, Dynatech Lab, Chantilly, VA) were coated with the enriched colonic peptide at a concentration of $0.5 \mu \mathrm{g} /$ well in $100 \mathrm{microlitre}$ of carbonate buffer, $\mathrm{pH} 9 \cdot 6$, overnight at $4^{\circ} \mathrm{C}$. Thereafter, wells were washed with phosphate buffered saline (PBS), $\mathrm{pH} 7 \cdot 4$, containing $0 \cdot 1 \%$ TWEEN-20 (PBS-TWEEN 20). Plates were blocked with $3 \%$ bovine serum albumin diluted in PBS for two hours at room temperature. Each serum was diluted 200 -fold in the blocking buffer. One hundred microlitre of the diluted serum was added per well in triplicate, incubated for two hours at $37^{\circ} \mathrm{C}$, and washed. Then the plates were treated as follows: (a) for the detection of total IgG, the plates were incubated with $100 \mu \mathrm{l} /$ well of 1:5000 diluted alkaline phosphatase conjugated donkey antiHuIgG $(\mathrm{H}+\mathrm{L})$ (Jackson Laboratories, West Grove, PA); (b) for detection of IgG subclasses, the plates were incubated for one hour at $37^{\circ} \mathrm{C}$ with $100 \mu \mathrm{l} /$ well of murine monoclonal anti-HuIgG1 (1:2000), anti-HuIgG2 (1:200), and anti-HuIgG3 (1:100) antibodies (Miles Scientific, Naperville, IL). Bound monoclonal antibodies were detected by alkaline phosphatase conjugated goat antimouse IgG (1:1000) (Zymed Lab, South San Francisco, CA). Finally, the chromogen p-nitrophenyl phosphate (Sigma Chemicals, St Louis, MO) was added in $1 \mathrm{mM}$ magnesium chloride and $50 \mathrm{mM}$ sodium carbonate, $\mathrm{pH} 9 \cdot 8$. Blanks consisted of protein coated wells that received similar treatment except human serum. Additional control experiments were performed using Escherichia coli extract. $E$ coli, strain Y1090, was grown in standard Luria-Bertani medium, washed with PBS three times, and lysed by sonication. Debris was removed by centrifugation and soluble proteins were precipitated by cold acetone and dried. Dried powder was reconstituted in carbonate buffer, $\mathrm{pH} 9 \cdot 6$, protein estimated by Biorad protein assay, and the ELISA plate was coated at a concentration of $0.5 \mu \mathrm{g}$ per well. Subsequent steps were the same as described above using human serum. The plates were read at $405 \mathrm{~nm}$ using a V max kinetic microplate reader (Molecular Devices, Menlo Park, CA). The mean blank values were deducted from the experimental values.

SANDWICH ELISA USING PURIFIED SERUM IgG1 AND $7 \mathrm{E}_{12} \mathrm{H}_{12}$ IgM

Purification of IgG1 from serum using antihuman IgG1 affinity column

Monoclonal antibody to human IgG1 (Calbiochem, San Diego, CA) was mixed with Affinica (S\&S, Keene, NH), tresyl activated 
TABLE I Serum samples from patients with IBD and controls

\begin{tabular}{llc}
\hline Serum samples $(n)$ & Disease activity and treatment & No of subjects \\
\hline UC (111) & Symptomatic, untreated & 63 \\
& Symptomatic, treated with corticosteroids` & 26 \\
CD (47)† & Remission & 22 \\
Colitides (29)‡ & S Symptomatic, untreated & 40 \\
Systemic lupus erythematosus (10) & S Remission & 7 \\
Normal subjects (16) & Symptomatic, untreated & 29 \\
& Healthy & 10 \\
& & 213
\end{tabular}

$\star>15 \mathrm{mg}$ prednisone. $\nmid 30$ of $47 \mathrm{CD}$ patients had colonic involvement. $\ddagger$ Shigella $(7)$, salmonella (6), giardia (6), amoebiasis (5), cryptosporidia (3), Cl difficile (2).

agarose $(2 \mathrm{ml})$ at a concentration of $1 \mathrm{mg} / \mathrm{ml}$ in coupling buffer $\left(0 \cdot 1 \mathrm{M} \mathrm{NaHCO}_{3}, \mathrm{pH} 8 \cdot 5\right)$. The gel suspension was treated with $1 \mathrm{M}$ ethanolamine $(\mathrm{pH} 8.5)$ to inactivate the unreacted tresyl group. The gel was washed alternately with acetate (pH 4.5) and carbonate (pH 8.5) buffers. Finally the gel was washed with PBS (pH 7.4) and packed into a column under gravity.

Five hundred microlitre of serum (delipidated and filtered) was mixed with equal volume of binding buffer (Pierce, Rockford, IL) and loaded onto the column under gravity. The column was washed extensively with the binding buffer to remove the non-specifically absorbed materials. The IgG1 was eluted with five bed volumes of elution buffer (Pierce), dialysed extensively against $10 \mathrm{mM}$ TRIS buffer saline ( $\mathrm{pH} 8 \cdot 0)$, and the protein concentration was measured. The purity and reactivity of IgG1 were examined by SDS-PAGE and by an ELISA. Each of the 10 samples including four patients with UC, three with $\mathrm{CD}$, and three normal subjects was used for purification of IgG1.

\section{Purification of $7 E_{12} \mathrm{H}_{12} \mathrm{IgM}$}

IgM was purified from mouse ascites fluid using an IgM purification kit (Pierce). Briefly, ascites was developed in pristane primed BALB/C mice using $7 \mathrm{E}_{12} \mathrm{H}_{12}$ hybridoma cells injected intraperitoneally $1 \times 10^{6}$ cells/mouse. The ascitic fluid was dilipidated by treating with 1,1,2-trichlorotrifluorethene and clarified through a $0.22 \mu \mathrm{m}$ syringe filter. One $\mathrm{ml}$ of clarified ascites was buffered with $20 \mathrm{mM}$ TRIS, $1.25 \mathrm{M}$ sodium chloride $\mathrm{pH} 7 \cdot 4$, and diluted 1:1 with immunopure IgM binding buffer (Pierce). One $\mathrm{ml}$ of cold $\left(4^{\circ} \mathrm{C}\right)$ diluted sample was applied to $5 \mathrm{ml}$ column of mannan binding protein immobilised on $4 \%$ beaded agarose and allowed to completely enter the gel. Two $\mathrm{ml}$ of binding buffer was added to the top of the column. The sample was allowed to incubate with the column at $4^{\circ} \mathrm{C}$ for 30 minutes, washed with binding buffer to remove unbound protein. The column was then eluted with immunopure IgM elution buffer at room temperature (Pierce). A three $\mathrm{ml}$ fraction was collected and elution was monitored using absorbance reading at $280 \mathrm{~nm}$. Protein containing fractions were pooled and dialysed and stored in $100 \mathrm{mM}$ TRIS, $\mathrm{pH} 8.0$, containing $50 \%$ glycerol. The purity of the IgM was examined by SDS-PAGE and by an ELISA using antimouse IgM ( $\mu$ chain specific) antibody.
Sandwich ELISA

Two sets of sandwich ELISAs were performed to capture the antigen(s) and examine the cross reactivity of the antigen by purified IgG1 and $7 \mathrm{E}_{12} \mathrm{H}_{12}$ IgM.

(1) The microtitre plate was coated with purified serum IgG1 from each of the 10 subjects in a concentration of $1 \mu \mathrm{g} /$ well in triplicate $/ 100 \mu$ l of coating buffer ( $\mathrm{pH} 9 \cdot 6)$ and left at $4^{\circ} \mathrm{C}$ for overnight. The next day, after washing three times in PBS/TWEEN 20 $(0 \cdot 1 \%)$, the plate is blocked with $0.25 \%$ bovine serum albumin in PBS. After this, sequential steps included incubation with FPLC purified $0.48 \mathrm{M} \mathrm{NaCl}$ mucosal extract (enriched colonic peptide) $(2 \mu \mathrm{g} /$ well $)$, for one hour at $37^{\circ} \mathrm{C}$, washed with PBS/TWEEN 20, and then incubated with $7 \mathrm{E}_{12} \mathrm{H}_{12} \operatorname{IgM}(1 \mu \mathrm{g} /$ well) for one hour at $37^{\circ} \mathrm{C}$, followed by alkaline-phosphatase conjugated antimouse IgM (Zymed, $1: 15000$, one hour at room temperature). Substrate buffer was added as described above and optical density was measured at $405 \mathrm{~nm}$ in the ELISA reader. The binding of IgG1 to the plate was confirmed with alkaline-phosphatase labelled antihuman IgG run in parallel. Antigen control included similarly extracted small intestinal protein(s) in place of $0.48 \mathrm{M}$ $\mathrm{NaCl}$ colon extract and an unrelated murine IgM monoclonal antibody (MOPC-104E) was used as control in place of $7 \mathrm{E}_{12} \mathrm{H}_{12}$ IgM.

(2) The microtitre plate was coated with purified $7 \mathrm{E}_{12} \mathrm{H}_{12} \operatorname{IgM}$ to capture the antigen. The plate was coated with $7 \mathrm{E}_{12} \mathrm{H}_{12}$ IgM $(0.5$ $\mu \mathrm{g} /$ well) followed by $0.48 \mathrm{M} \mathrm{NaCl}$ colon extract and then with purified human serum IgG1. Detection system in this case was alkaline phosphatase labelled goat antihuman IgG.

\section{Results}

Table I shows the demographic data of the 203 subjects. These included 63 patients with symptomatic UC without any treatment, 26 patients with symptomatic UC who were treated with corticosteroids or immunosuppressive drugs, or both and 22 patients with UC in remission. Additional samples were obtained from 40 patients with symptomatic $\mathrm{CD}$ who did not receive any drugs other than sulphasalazine, and seven patients with $C D$ in remission; 29 symptomatic patients with diarrhoea resulting from various pathogenes, 16 healthy subjects, and 10 patients with systemic lupus erythematosus. The patients with UC ranged in age from 9 to 83 years (mean age 40) and 52 patients were men. The duration of their disease varied from two months to 22 years (mean $6 \cdot 1$ years). The patients with $C D$ ranged in age from 12 to 67 years (mean 36 ). The duration of CD ranged from two months to 40 years (mean $7 \cdot 38$ years). Patients with both UC and CD with active disease and who were not receiving drugs were not treated with corticosteroids or other immunosuppressive drugs at the time of collection of serum samples. However, several patients were taking sulphasalazine or other 5-ASA preparations. Serum samples were also obtained from 29 patients with acute diarrhoea caused by 


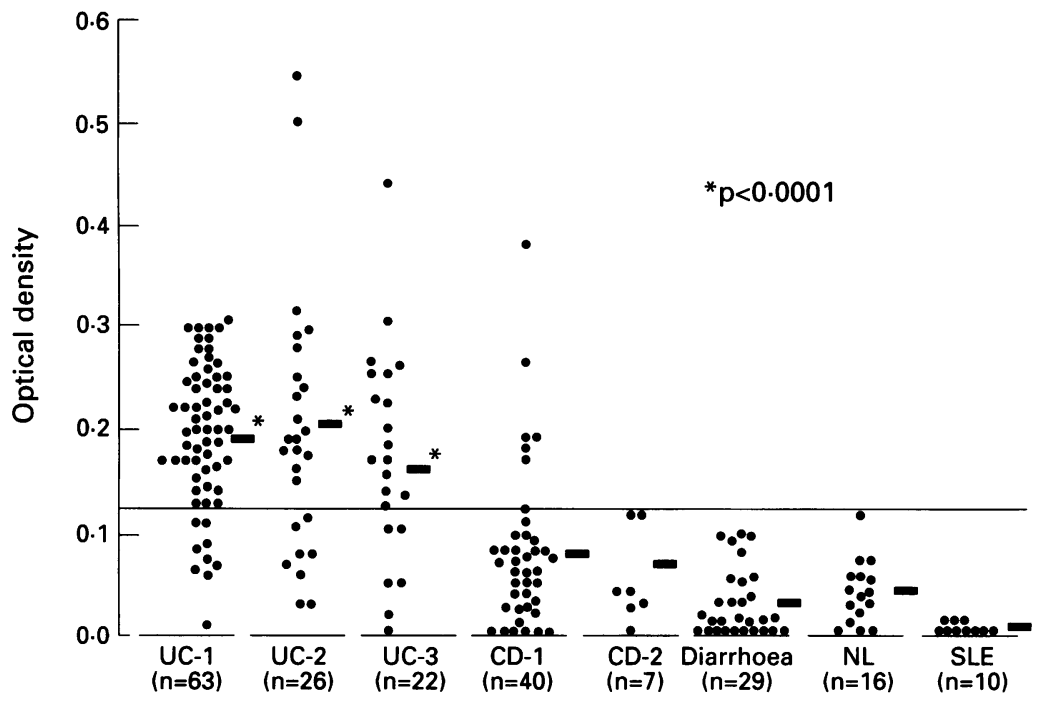

Patients

Figure 1: Scatterogram showing the IgG1 antibody response against the colonic extract highly enriched in the colonic peptide reactive to $7 E_{12} H_{12}$ monoclonal antibody. Patients with UC belonged to three groups: UC-1, symptomatic and untreated; UC-2, symptomatic and treated with corticosteroids or immunosuppressive drugs; UC-3, patients in remission. Patients with $C D$ included $C D-1$, symptomatic and untreated and $C D-2$, the patients in remission. Thirty $C D$ patients had colonic involvement with or without ileal involvement. Patients with colitides caused by specific pathogens are identified as patients with diarrhoea. NL-normal subjects and SLE-systemic lupus erythematosus. The highest background value of this ELISA with a normal serum was an optical density of $0 \cdot 125$. Eighty eight of 111 UC serum samples (79\%) and only six of 47 CD serum samples had optical density values above this baseline. Each of the UC group had significantly $(p<0.0001)$ higher optical density when compared with any of the non-UC groups.

specific pathogenes, which, as identified by stool examinations, were: shigella (6); salmonella (6); giardia (5); amoebiasis (4); cryptosporidia (4); $\mathrm{Cl}$ difficile (1); blastocystis (2), and intestinal tuberculosis (1).

The immunoreactivity of $7 \mathrm{E}_{12} \mathrm{H}_{12}$ monoclonal antibody increased in various colonic mucosal extracts during the purification in FPLC. A 21-fold enrichment of the immunoreactivity of $7 \mathrm{E}_{12} \mathrm{H}_{12}$ monoclonal antibody was seen in the $0.48 \mathrm{M} \mathrm{NaCl}$ eluate. This eluate containing the enriched colonic peptide was used for both direct and sandwich ELISAs. The enriched colonic peptide was further characterised as follows: the $7 \mathrm{E}_{12} \mathrm{H}_{12}$ reactive peptide is heat stable and the reactivity does not change after boiling and it reacts with concanavalin A, suggesting that it is a glycoprotein. The reactivity of $7 \mathrm{E}_{12} \mathrm{H}_{12}$ is, however, against the peptide rather than sugar. This is evidenced by the fact that periodate treatment $^{12}$ and $N$ - and $O$-glycanase treatments ${ }^{13}$

TABLE II Mean optical densities (SEM) and statistical analysis of total IgG and IgG1 antibody responses in serum samples against the enriched colonic peptide

\begin{tabular}{llll}
\hline \multirow{2}{*}{ Serum samples (n) } & & $\begin{array}{l}\text { Total IgG response } \\
\text { optical density (SEM)an }\end{array}$ & $\begin{array}{l}\text { IgG1 responsełt (mean } \\
\text { optical density (SEM)) }\end{array}$ \\
\hline UC & 1 Active, untreated (63) & $0.190(0.014)$ & $0.199(0.009)$ \\
& 2 Active, treated (26) & $0.128(0.018)$ & $0.204(0.024)$ \\
CD & 3 Remission (22) & $0.108(0.016)$ & $0.160(0.018)$ \\
& 1 Active, untreated (40) & $0.096(0.012)$ & $0.077(0.012)$ \\
Colitides & 2 Remission (7) & $0.108(0.020)$ & $0.067(0.014)$ \\
Systemic lupus & Active (29) & $0.079(0.012)$ & $0.028(0.006)$ \\
erythematosus & Active (10) & Not done & $0.009(0.005)$ \\
Normal subjects & Healthy (16) & $0.073(0.009)$ & $0.040(0.008)$ \\
& &
\end{tabular}

*Statistical significance for total IgG response: UC-1 $v$ CD-1, $\mathrm{p}<0 \cdot 001$; UC-1 or UC-2 $v$ colitides, $\mathrm{p}<0.05$ to 0.001 ; UC-1 or UC-2 $v$ normal subjects, $\mathrm{p}<0.05$ to 0.001 ; UC-3 $v \mathrm{CD}$, colitides or normals, not significant.

† Statistical significance for IgG1 response: UC-1, UC-2, or UC-3 $v$ CD-1 or CD-2, $<<0.001$ to 0.0001 ; UC-1, UC-2, or UC-3 $v$ colitides, $\mathrm{p}<0.0001$; UC-1, UC- 2 , or UC- $3 v$ systemic lupus erythematosus, $\mathrm{p}<0.0001$; UC- 1 , UC-2, or UC-3 $v$ normal controls, $\mathrm{p}<0.0001$. do not change the $7 \mathrm{E}_{12} \mathrm{H}_{12}$ monoclonal antibody reactivity; whereas trypsin digestion destroys the activity.

Figure 1 shows the ELISA data of IgG1 antibody responses with all 213 subjects. The highest background value of this ELISA with a non-inflammatory bowel disease subject was an optical density of $0 \cdot 125$ with a normal serum. The mean (SEM) value for all normal subjects was $0.040(0 \cdot 008)$. Eighty eight serum samples from the total $111(79 \%)$ UC patients produced an optical density higher than $0 \cdot 125$. Only six of $47 \mathrm{CD}$ serum samples $(12 \%)$ had an optical density value higher than $0 \cdot 125$. Table II summarises the results in all patients with different clinical activities and their statistical analysis. The mean (SEM) value for UC group with symptomatic disease without any treatment was $0 \cdot 199(0.009)$, symptomatic UC treated with corticosteroids was 0.204 $(0.024)$; UC in remission was $0.160(0.018)$. The mean value for $C D$ group with active disease was $0.077(0.012)$ and for CD patients in remission it was $0.067(0.014)$. The mean value for symptomatic diarrhoeal patients was $0.028(0.006)$ and for systemic lupus erythematosus patients the mean optical density value was $0.009(0.005)$. The difference between the mean value for each of the UC subgroups (treated or untreated, symptomatic or in remission) is highly significant $(p=<0.001$ to 0.0001$)$ against each non-UC group (Table II). There was no difference in IgG2 and the IgG3 responses. IgG4 response was not examined.

Table II also shows the total IgG antibody response in the UC group, particularly patients with symptomatic colitis without being treated, the mean (SEM) optical density was the highest at $0 \cdot 190(0.014)$ followed by symptomatic patients who were treated. The background optical density for total IgG with normal subjects and diarrhoeal patients was 0.073 and 0.079 respectively; patients with active $C D$ and UC in remission had mean optical density values 0.096 and $0 \cdot 108$ respectively. Statistical analysis of total Igs responses showed that only symptomatic patients with UC treated or untreated had significantly higher $(p=<0.05$ to $<0.001$ ) optical density than each of the non-UC group. The optical density value in patients with UC in remission, however, was not significantly different than any of the nonIBD group.

The IgG1 responses against the $E$ coli extract was measured with $20 \mathrm{UC}, 10 \mathrm{CD}$, and 10 normal serum samples. The mean (SEM) optical density values for UC, CD, and normal subjects were $0.161(0.018), 0.212$ $(0.055)$, and $0.238(0.039)$ respectively. The differences among these values were not statistically significant. The total IgG response in UC $(0.487(0.064))$ was also similar to normal subjects $(0.479(0.083))$.

Figure 2 and Table III shows the results of the capture ELISA using the enriched colonic peptide and purified IgG1 or $7 \mathrm{E}_{12} \mathrm{H}_{12}$ IgM. The peptide bound to UC IgG1 also bound to $7 \mathrm{E}_{12} \mathrm{H}_{12}$ monoclonal antibody and vice versa, showing the cross reactivity of the two 

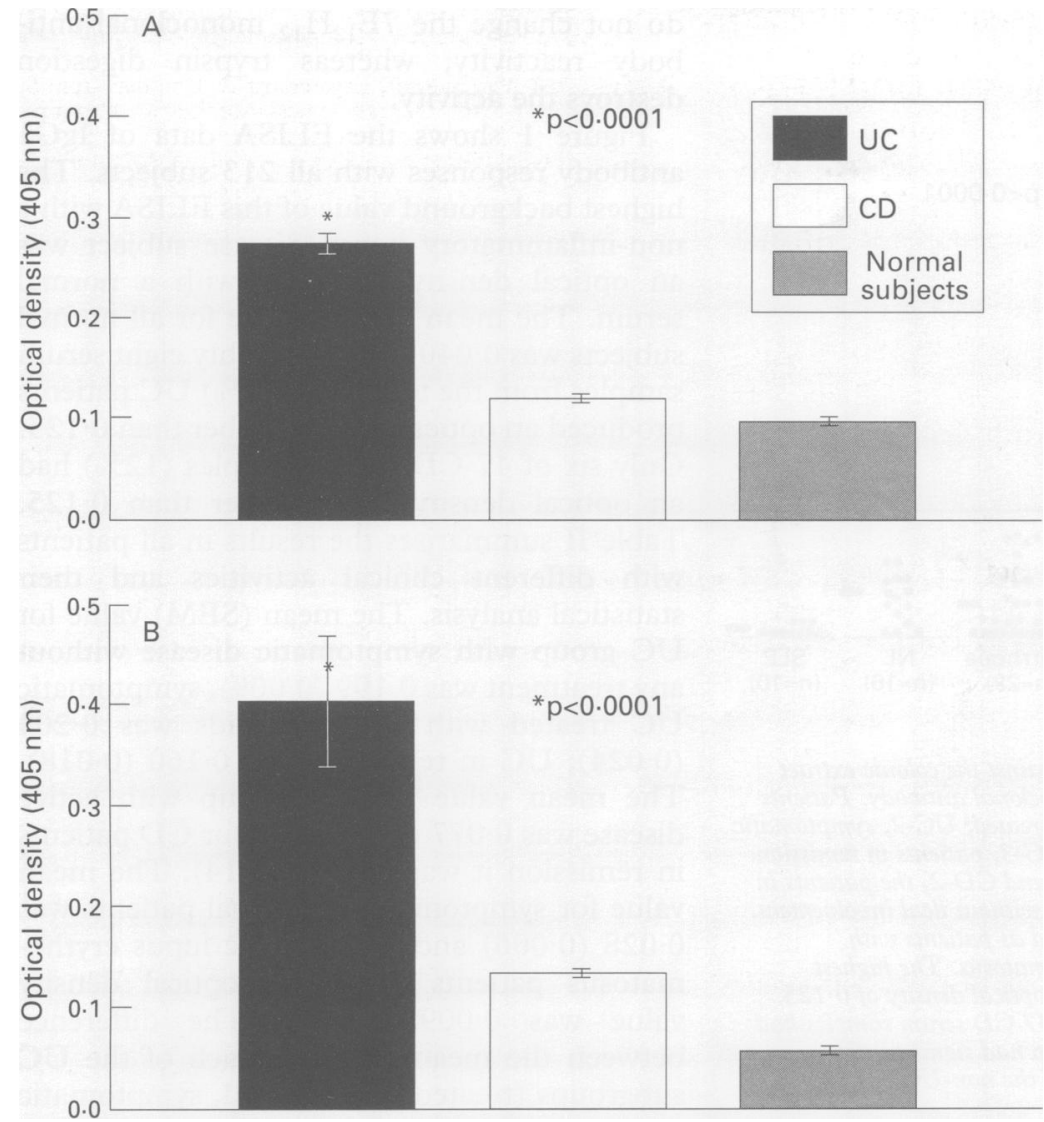

Figure 2: Sandwich ELISA to examine the cross reactivity of the antigen against purified serum IgG1 and $7 E_{12} H_{12}$ IgM monoclonal antibody. (A) The antigen was captured by coating the plate with purified serum IgG1 and then the reactivity of purified $7 E_{12} H_{12}$ IgM against the antigen was tested; $(B)$ the antigen was first captured by coating the plate with $7 E_{12} H_{12}$ IgM and the reactivity was examined using serum IgG1. A highly significant $(p<0 \cdot 0001)$ reactivity was evident in $U C$ in both $(A)$ and $(B)$.

antibodies against the same peptide. Such reactivity was not seen with CD-IgG1 MOPC$104 \mathrm{E}$, and when small intestinal mucosal extract was used in place of enriched colonic peptide (Fig 2 and Table III).

\section{Discussion}

In this study, we show that almost $80 \%$ of the patients with UC, symptomatic or in remission, treated or untreated had specific IgG1 autoantibody $(p=0.0001)$ directed against the colon extract highly enriched for $7 \mathrm{E}_{12} \mathrm{H}_{12}$ reactive peptide. Only six of $47(12 \%)$ patients with CD reacted. Serum samples from 29 patients with colitides caused by specific pathogens, serum from patients with systemic lupus erythematosus, and normal subjects did not react, however, with the peptide in the direct ELISA. The sandwich ELISAs using purified serum IgG1 and $7 \mathrm{E}_{12} \mathrm{H}_{12}$ IgM further confirmed that the IgG1 autoantibody in UC indeed reacts with the colonic protein also recognised by the $7 \mathrm{E}_{12} \mathrm{H}_{12}$ monoclonal antibody. That the IgG1 response in UC is specific to the colonic peptide rather than a general antibody response, is supported by the fact that the IgG antibody response in UC against the $E$ coli extract was not subclass specific.

The total IgG reactivity using the UC serum samples showed only $50 \%$ sensitivity with $25 \%$ false positive for CD. Similar results were reported by us earlier using $0.35 \mathrm{M} \mathrm{NaCl}$ eluate of colon extract. ${ }^{14}$ We did not perform IgG subtype specific ELISAs in this earlier study. Thus, the IgG antibody response in the absence of subclass specific ELISA would not have detected the UC specific response against the colonic peptide as shown here. The high background activity with total IgG can be explained because of the presence of nonspecific proteins still present in the colon extracts.

Hibi et al ${ }^{15}$ described in vitro synthesis of anti-colon epithelial antibody by mucosal and peripheral blood lymphocytes from UC. We earlier described colon tissue bound IgG antibodies, termed CCA-IgG ${ }^{9}$ in UC patients and not in patients with $C D$, diverticulitis and normal subjects. CCA-IgG recognises an $\mathrm{Mr}$ $40 \mathrm{~K}$ protein present in the colonic extracts. To study this antigen further, we developed a monoclonal antibody of the IgM isotype designated $7 \mathrm{E}_{12} \mathrm{H}_{12}$, which exclusively binds with the colonic epithelium mainly along the plasma membrane at the basolateral and apical or luminal aspects of the epithelial cells. ${ }^{10}$ Using immunofluorescent assay, the organ specificity of $7 \mathrm{E}_{12} \mathrm{H}_{12}$ monoclonal antibody to the colonic epithelium with more intense expression in the rectum has been reported recently by Halstensen et al. ${ }^{11}$ Although the subtype of CCA-IgG was not analysed, it inhibited the binding of $7 \mathrm{E}_{12} \mathrm{H}_{12}$ monoclonal antibody to the colonic peptide, suggesting that both antibodies probably react with the same peptide. ${ }^{10}$ The reactive peptide recognised by the $7 \mathrm{E}_{12} \mathrm{H}_{12}$ monoclonal antibody has since been localised also in epithelial cells of the skin and biliary tract, ${ }^{16}$ the extra colonic organs often involved in UC. In animal models of spontaneous colitis such as that seen in Saguinus oedipus (cotton top tamarins) a similar distribution of $7 \mathrm{E}_{12} \mathrm{H}_{12}$ monoclonal antibody was seen in the colon epithelium. ${ }^{17}$ The small intestine of the cotton top tamarins did not react. Furthermore, serum from cotton top tamarins with spontaneous colitis had circulating antibodies against the $7 \mathrm{E}_{12} \mathrm{H}_{12}$ reactive peptide, whereas normal cotton top tamarins did not. ${ }^{17}$ These data suggest an autoantigenic role of $7 \mathrm{E}_{12} \mathrm{H}_{12}$ reactive peptide. Using a triple colour immunofluorescence technique, recently IgG1 autoantibody was shown to

TABLE III The immunoreactivity of serum IgG1 and $7 E_{12} H_{12}$-IgM monoclonal antibody against FPLC enriched colonic peptide by the sandwich ELISA, where the plate was coated with purified IgG1 followed by enriched colonic peptide and then $7 E_{12} \mathrm{H}_{12}$ IgM*

\begin{tabular}{llll}
\hline & \multicolumn{2}{l}{ Optical density (SEM) $\dagger$} \\
\cline { 2 - 4 } & Enriched colonic & Enriched colonic & E SI extract \\
peptide + & peptide ${ }^{+}$ & + \\
& $7 E_{12} H_{12}$ & MOPC & $7 E_{12} H_{12}$ \\
\hline UC & $0.177(0.010) \neq$ & $0.015(0.005) \|$ & $0.016(0.009)$ \\
CD & $0.021(0.004) \oint$ & $0.010(0.002)$ & $0.014(0.006)$ \\
\hline
\end{tabular}

*When the plate was first coated with $7 \mathrm{E}_{12} \mathrm{H}_{12}$ IGM followed by enriched colonic peptide and then with serum IgG1 the mean optical density value for UC was 0.344 and for $C D$ it was 0.076 . This difference was statistically highly significant, $\mathrm{p}=<0.0001$.

†The background value for normal serum IgG1 is deducted from all samples.

$\ddagger v \S$, $\|$, or $\llbracket=\mathrm{p}<0.0001$. E SI extract $=$ enriched small intestinal mucosal extract. 
colocalise with $7 \mathrm{E}_{12} \mathrm{H}_{12}$ monoclonal antibody and activated complement products in the colonic mucosa of patients with $\mathrm{UC}^{11}$ but not $\mathrm{CD},{ }^{8}$ further supporting the notion that the $7 \mathrm{E}_{12} \mathrm{H}_{12}$ reactive peptide acts as an autoantigen capable of inducing IgG1 autoantibody in UC and can activate complement mediated colonic cell injury. The postulated IgG1 mediated epithelial attack by the $7 \mathrm{E}_{12} \mathrm{H}_{12}$ reactive peptide is also supported by the finding that peripheral blood lymphocytes from patients with UC (but not controls) and lamina propria lymphocytes from UC mucosa spontaneously release IgG1 antibodies to the colonic peptide. ${ }^{18}$ Several studies reported that UC serum samples and not CD samples can induce antibody dependent cell mediated cytolysis against specific colon cancer cell targets. ${ }^{19-21}$ Antibody dependent cell mediated cytolysis induced by UC serum samples on DLD-1 colon cancer cells that express $7 \mathrm{E}_{12} \mathrm{H}_{12}$ reactive peptide could be blocked by the $7 \mathrm{E}_{12} \mathrm{H}_{12}$ monoclonal antibody, suggesting that the $7 \mathrm{E}_{12} \mathrm{H}_{12}$ reactive peptide participates in antibody dependent cell mediated cytolysis in UC. ${ }^{22}$ The absence of antibody dependent cell mediated cytolysis with UC serum sample, against another colon cancer cell line, HT-29 as reported by Snook et al, ${ }^{23}$ may result from the absence of the $7 \mathrm{E}_{12} \mathrm{H}_{12}$ reactive peptide in these cells. ${ }^{24}$ The predominating mucosal IgG1 response in UC may be genetically determined, as suggested by the identical twins study. ${ }^{25}$

To summarise, our data provide evidence that circulating antibody of IgG1 subclass against the colonic peptide reactive to the $7 \mathrm{E}_{12} \mathrm{H}_{12}$ monoclonal antibody exists in most (at least three quarters) of the patients with UC. Thus, these findings strongly support previous in situ data ${ }^{11}$ and provide further evidence that an autoimmune response to the $7 \mathrm{E}_{12} \mathrm{H}_{12}$ reactive peptide is an important immunopathological mechanism in UC. Further characterisation of the peptide, reactive to $7 \mathrm{E}_{12} \mathrm{H}_{12}$ monoclonal antibody, may elucidate the mechanism of autoimmune response in UC.

This work is supported in part by research grants RO1 DK44314 and DK47673 from the National Institute of Health, Bethesda, MD, USA.

1 Das KM. Autoimmunity in inflammatory bowel disease. Can $\mathcal{F}$ Gastroenterol 1993; 7: 102-9.

2 Broberger O, Perlmann P. Autoantibodies in human Broberger O, Perlmann P. Autoantibodies in
ulcerative colitis. $\mathcal{J}$ Exp Med 1959; 110: 657-73.

3 Hibi $T$, Aiso $M$, Ishikawa $M$, Watanabe $M$, Yoshida $T$, Kobayashi $\mathrm{K}$, et al. Circulating antibodies to the surface antigens on colon epithelial cells in ulcerative colitis. Clin Exp Immunol 1983; 54: 163-8.

4 Aronson RA, Cook SL, Roche JK. Sensitization to epithelial antigens in chronic mucosal inflammatory disease. I
Purification, characterization and immunoreactivity of epithelial cell associated components (ECAC). $\mathcal{F}$ Immunol 1983; 131: 2796-844.

5 Zeromski J, Perlmann P, Lagercrantz R, Hammarstrom S, Gustafsson BE. Immunological studies in ulcerative colitis VIII. Anticolon antibodies of different colitis VIII. Anticolon antibodies of different

immunoglobulin classes. Clin Exp Med 1970; 7: 469-75.
6 MacDermott RP, Nash GS, Auer IO. Alteration in serum immunoglobulin subclasses in patients with ulcerative colitis and Crohn's disease. Gastroenterology 1989; 96: 764-8.

7 Halstensen TS, Mollness TE, Garred P, Fausa O, Brandtzaeg P. Epithelial deposition of immunoglobulin G1 and activated complement (C3b and terminal complement complex) in ulcerative colitis. Gastroenterology 1990; 98: $1264-71$.

8 Halstensen TS, Mollnes TE, Garred P, Fausa O, Brandtzaeg P. Surface epithelium related activation of complement differs in Crohn's disease and ulcerative colitis. Gut 1992; 33: 902-8.

9 Takahashi F, Das KM. Isolation and characterization of a colonic autoantigen specifically recognized by colon tissue-bound IgG from idiopathic ulcerative colitis. $\mathcal{F}$ Clin tinvest 1985; 76: 311-8.

10 Das KM, Sakamaki S, Vecchi M, Diamond B. The production and characterization of monoclonal antibodies to human colonic antigen associated with ulcerative colitis: cellular localization of the antigen by using the monoclonal antibody. F Immunol 1987; 139: 77-84.

11 Halstensen TS, Das KM, Brandtzaeg P. Epithelial deposits of immunoglobulin $\mathrm{G1}$ and activated complement colocalise with the $M_{r} 40 \mathrm{kD}$ putative autoantigen in ulcerative colitis. Gut 1993; 34: 650-7.

12 Woodward MP, Young WW, Bloodgood RA. Detection of monoclonal antibodies specific for carbohydrate epitopes using periodate oxidation. $\mathcal{F}$ Immunol Methods 1985; 78: using perioc

13 Thotakura NR, Bahl OM. P. Enzymatic deglycosylation of glyco-proteins. Methods Enzymol 1987; 138: 350-4.

14 Takahashi F, Shah HS, Wise LS, Das KM. Circulating antibodies against human colon extract enriched with a 40 KDa protein in patients with ulcerative colitis. Gut 1990; 31: $1016-20$

15 Hibi T, Toda K, Hara K, Ogata H, Iwao Y, Watanabe N, et al. In vitro anticolonic antibody production by muscular or peripheral blood lymphocytes from patients with ulcerative colitis. Gut 1990; 31: 1371-6.

16 Das KM, Vecchi M, Sakamaki S. A shared and unique epitope(s) in human colon, skin and biliary epithelium detected by a monoclonal antibody. Gastroenterology 1990; 98: 464-9.

17 Das KM, Vecchi M, Squillante L, Dasgupta A, Henke $M$, Clapp N. Mr 40000 human colonic epithelial protein expression in colonic mucosa and presence of circulating expression in colonic mucosa and presence of circulating
anti-Mr 40000 antibodies in cotton top tamarins with anti-Mr 40000 antibodies in cotton top

18 Biancone L, Dasgupta T, Paoluzi OA, DiPaolo MC, Pallone F, Das KM. Lamina propria cells from colonic mucosal biopsy specimens of patients with ulcerative colitis secrete $\operatorname{IgGl}$ antibodies that recognize colonic protein(s) enriched with the $\mathrm{Mr} 40 \mathrm{~K}$ protein. Gastroenterology 1992; 102: A595.

19 Nagai T, Das KM. Demonstration of an assay for specific cytolytic antibody in sera from patients with ulcerative colitis. Gastroenterology 1981; 80: 1507-12.

20 Das KM, Kadono Y, Fleischner G. Antibody dependent, cell mediated cytotoxicity in serum samples from patients with ulcerative colitis. Am 7 Med 1984; 77: 791-6.

21 Auer IO, Grosch L, Hardorfer C, Roder A. Ulcerative colitis specific cytotoxic IgG autoantibodies against colon colitis specific cytotoxic lgG autoantibodies again cancer cell. Gut 1988; 29: 1639-47.

22 Biancone L, Das KM, Ebert EC. The Mr 40000 colonic protein is associated with antibody-dependent cellmediated cytolysis (ADCC) by ulcerative colitis (UC) sera. Digestion 1993; 54: 237-42.

23 Snook JA, Lowes JR, Wu KC, Priddle DP, Jewel DP Serum and tissues autoantibodies to colonic epithelium in ulcerative colitis. Gut 1991; 32: 163-6.

24 Hassan T, Kanisawa Y, Squillante L, Meyers S, Das KM Expression of a unique epitope in limited colon cancer cell lines that reacts with a novel monoclonal antibody, $7 \mathrm{E}_{12} \mathrm{H}_{12}$ and ulcerative colitis (UC) serum. $7 \mathrm{E}_{12} \mathrm{H}_{12}$ and ulcerative colit

25 Helgeland L, Tysk C, Jarnerot G, Kett K, Lindberg E, Danielsson D, et al. The Ig G-subclass distribution in serum and rectal mucosa of monozygotic twins with or serum and rectal mucosa of monozygotic twins with or
without inflammatory bowel disease. Gut 1992; 33: without infl.
$1358-64$. 